\title{
Navicula nielsfogedii J.C. TAYlor \& COCQUYT sp. nov., a new diatom (Bacilla- riophyta) from tropical and sub-tropical Africa
}

\author{
Jonathan C. TAYLOR ${ }^{1,2,3^{*}}$, Christine COCQUYT $^{1} \&$ Shigeki MAYAMA $^{4}$
}

\author{
${ }^{1}$ Botanic Garden Meise, 38 Nieuwelaan, Meise 1860, Belgium \\ ${ }^{2}$ School of Biological Sciences, North-West University, P Bag X6001, Potchefstroom 2520, South Africa; *Cor- \\ responding author e-mail: Jonathan.Taylor@nwu.ac.za \\ ${ }^{3}$ South African Institute for Aquatic Biodiversity (SAIAB), P Bag 1015, Grahamstown 6140, South Africa \\ ${ }^{4}$ Department of Biology, Tokyo Gakugei University, Koganei, Tokyo 184-8501, Japan
}

\begin{abstract}
In this paper we describe Navicula nielsfogedii sp. nov., a commonly occurring diatom through central and southern Africa and distributed from the sub-tropical zones of South Africa to tropical central Africa. We have examined the material of the most closely related species described from Africa, Navicula feuerbornii f. africana FogED and suggest that this species may be conspecific with Navicula heimansioides LANGE-Bertalot and to have no link to the taxon N. feuerbornii Hustedt sensu Simonsen. With reference to Navicula feuerbornii f. africana we also discuss the changes over time in diatom species concepts, what we have dubbed 'species concept drift', and the consequences this holds for accurately identifying diatom taxa. As the newly described species is widely distributed and common in some samples from tropical and subtropical Africa we conclude that it may be a useful additional indicator organism for water quality monitoring in the region.
\end{abstract}

Key words: Congo River, diatoms, DR Congo, Navicula nielsfogedii, new species, taxonomy, tropical Africa

\section{INTRODUCTION}

Navicula BoRY sensu lato was considered for the majority of the $20^{\text {th }}$ century as a large genus into which many biraphid diatoms with bi-lateral symmetry around the transapical axis could be placed. In the last two decades an increasing number of taxa have been split from Navicula and placed in new genera (e.g., Geissleria LANGE-BERTALOT et METZELTIN), or re-ascribed to previously described genera (e.g., Placoneis MereSCHOWSKy, Sellaphora MERESCHOWSKy) and the concept of Navicula as a genus has been restricted to Navicula sect. lineolatae (Round et al. 1990). Even with this restricted delimitation Navicula sensu stricto remains a source of taxonomic and nomenclatural confusion (e.g., the various names and combinations of species such as Navicula symmetrica R. M. PATRICK and N. schroeteri F. MEISTER). As with all diatom species, the naviculoid diatoms undergo what may be termed as 'species concept drift'. By this we mean that the original concept of the taxon established by the describing author becomes misinterpreted and changes over time, possibly due to the difficulty of interpreting line drawings. Often the species concept may also not have been made entirely clear by the author, for example $N$. feuerbornii HusTEDT (see discussion). For this reason many workers in the field of diatom studies are now referring directly to type materials in order to reduce taxonomic and nomenclatural confusion. In and of itself taxonomic and nomenclatural accuracy is important, however, when the diatoms are being used for water quality monitoring studies it is important that the names be applied to taxa in a consistent manner, this is especially true for taxa which dominate diatom assemblages.

Recent work in the field of biomonitoring and water quality studies in tropical and sub-tropical Africa have brought to light many such instances which have proved a major hindrance in the successful application of biomonitoring techniques, based on diatoms, in Africa. In this paper we describe and discuss the distribution of Navicula nielsfogedii $\mathrm{sp}$. nov. This is a rather commonly occurring taxon across sub-tropical and tropical Africa and has been found to dominate diatom assemblages in the Democratic Republic of the Congo (DRC) and thus accurate delimitation of this taxon is necessary. 


\section{Materials And Methods}

The sample (CCA 2071) containing Navicula nielsfogedii spec. nov. was obtained from wood substratum in the Lomami River at $0.49339^{\circ} \mathrm{N}$ and $24.19960^{\circ} \mathrm{E}$, Tshopo Province (part of the formerly Oriental Province), Democratic Republic of the Congo by François Darchambeau and Ernest Tambwe on 24 November 2012. The sample was fixed in situ in a $20 \%$ v.v. final concentration ethanol solution. Diatom samples for LM and SEM observations were prepared by oxidizing the material using $37 \% \mathrm{H}_{2} \mathrm{O}_{2}$ and heated to $100{ }^{\circ} \mathrm{C}$ for 1 to 2 hours. Following digestion the material was rinsed with distilled water. A subsample from the organic-free material was mounted in Naphrax ${ }^{\circledR}$ to obtain permanent diatom slides. Some physical parameters (temperature, conductivity and $\mathrm{pH})$ were measured in situ with an YSI ProPlus multiprobe field meter equipped with a $\mathrm{pH}$ sensor 1001 ProSeries. Samples from nutrient analyses $\left(\mathrm{NH}_{4}, \mathrm{NO}_{3}, \mathrm{NO}_{2}\right.$ and SRP) were filtered and acidified in situ, and kept frozen until spectrophotometric analysis in the laboratory of the Unité d'Océanographie Chimique, Département d'Astrophysique, Géophysique et Océanographie, University of Liège, Belgium.

The type slide of Navicula feuerbornii f. africana FoGED (Foged 1966, Ghana No. 119/1961) was obtained from the Museum Botanicum Hauniense, Copenhagen, Denmark.

Light microscope (LM) images were collected using a Olympus BX 51 microscope and a Nikon 80i microscope equipped with differential interference contrast optics and $100 \times 1.4$ N.A. oil immersion objective. LM micrographs were taken with a UC30 digital camera at the Botanic Garden Meise, and a Nikon DS Fil at the North-West University. The striae density and valve size were determined based on measurements of 70 valves.

For scanning electron microscopy (SEM), parts of the oxidized material was rinsed with additional deionized water and isolated with micropipette on $6 \times 6 \mathrm{~mm}$ cover slip. Cover slips were mounted on aluminium stubs and coated with osmium by OPC 40A osmium plasma coater (Filgen, Nagoya, Japan). A field emission scanning electron microscope S-8020 (Hitachi, Tokyo, Japan) operated at $5 \mathrm{kV}$ and 8 or $12 \mathrm{~mm}$ working distance was used for the analysis. The terminology used is that outlined in AnOnYmous (1975) and Ross et al. (1979).

\section{RESUlts}

Navicula nielsfogedii J.C. Taylor et Cocquyt sp. nov. (Figs 1-22, 34-51)

\section{Description}

Light Microscopy (Figs 1-22): Valves linear-elliptic to linear lanceolate with cuneate, more or less obtusely rounded, slightly protracted ends, length 22-43 $\mu \mathrm{m}$, width 5.3-6.7 $\mu \mathrm{m}$. Raphe filiform, central raphe endings close, both deflected to the primary side, to which the asymmetrically enlarged central nodule is also directed. Axial area very narrow; central area varying from rounded to elliptic, more or less lanceolate expanded on the secondary side and thus distinctly asymmetric. Striae radiate in the central area, becoming parallel round the Voigt discordance and finally convergent towards the apices, $16-18$ in $10 \mu \mathrm{m}$. Areolae comparatively dense, not possible to resolve in LM.

Scanning Electron Microscopy (Figs 34-51): Externally the raphe distinctly curved and central raphe endings deflected slightly to the primary side. A small structure, described as a silicate tongue in other Navicula taxa (Lange-Bertalot 2001) is present and appears to split the slightly expanded drop shaped central pores (Fig. 35-37) (cf. Navicula tripunctata (O. F. Müller) Bory, N. jakovljevicii Hustedt). However when this structure is examined more closely (Fig. 37) it becomes clear that it is a thin twisted bar of silica that extends down through the width of the cell wall and links the two sides of the central pore. Thus the structure cannot be accurately termed a silica tongue as it is linked at two locations. Axial area externally not thickened into a sternum. Voigt discordance clearly visible on the secondary side (Figs 34, 40). The stria closest to the apices consists of only a single areola from which a diagonal transapical slit extends giving the stria an inverted V-shape (Figs 38-39). A number of suture-like structures, similar to cranial sutures, (Figs 46-48) run from the raphe to the junction of the valve face and valve mantle on the external surface over the virgae (Figs 34-35), but not continuing on the valve mantle. These suture-like structures are dispersed from the central area up to the apices and are present in all of the geographically separate populations examined (DRC, Zambia and South Africa). Such structures were not reported in other diatoms and their value as taxonomic characteristics is unknown. Externally and internally the transapical striae are clearly broader than the virgae. Perforate hymenes occlude the areolae on the inside of the valve (Fig. 45), 40 areolae in $10 \mu \mathrm{m}$. The raphe sternum and additional rib are comparatively narrow (Figs 40-42). The raphe turns to a lateral position just behind the central nodule and up to the helictoglossae (Figs 43-44) (cf. N. capitatoradiata H. Germain and N. arkona Lange-Bertalot et Witkowski). Copulae are open without any perforation or ornamentation (Figs 49-51). Valvocopulae consist of a longer band and complementary short band restricted to the pole.

Holotype (designated here): slide BR 4397 from sample CCA 2071, Botanic Garden Meise, Belgium (BR). The valve representing the holotype is here illustrated in Figure 4.

Isotypes (designated here): slide PUC-13-572 from sample CCA 2071, South African Diatom Collection housed at North-West University, Potchefstroom, South Africa; slide ZU 10/29 from sample CCA 2071, Diatom Collection, Alfred-Wegener-Institue für Polar- und Meeresforschung, Bremerhaven, Germany (BRM).

Type locality: Lomami River, a major tributary of 
the Congo River downstream Kisangani, Tshopo Province (part of the formerly Oriental Province), DRC. $0.49339^{\circ} \mathrm{N}$ and $24.19960^{\circ} \mathrm{E}$

Etymology: The specific epithet honours the diatomist Niels Foged for his contribution to the knowledge of the diatom flora of Africa.

Ecology and Distribution: This taxon occurs commonly throughout the tropics and sub-tropics of southern and central Africa in freshwater rivers and streams. In general it occurs in slightly acidic to circumneutral, oligo- to mesotrophic waters with moderate conductivity. The type locality had the following characteristics at the time of collection: temperature

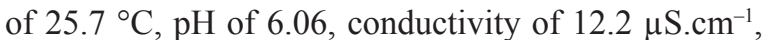
$0.06 \mathrm{mg} . \mathrm{l}^{-1} \mathrm{NH}_{4}, 0.009 \mathrm{mg} . \mathrm{l}^{-1} \mathrm{NO}_{2}, 0.45 \mathrm{mg} . \mathrm{l}^{-1} \mathrm{NO}_{3}$, and $0.09 \mathrm{mg} . \mathrm{l}^{-1} \mathrm{SRP}$.

\section{Discussion}

\section{Taxonomic comments}

Navicula nielsfogedii is at the first sight close to or similar to a number of previously described taxa. $\mathrm{Na}$ vicula leptostriata E. G. JøRGENSEN (JøRGENSEN 1948) overlaps $N$. nielsfogedii in terms of length $(25-35 \mu \mathrm{m}$ long), but is narrower $(4.5-5.5 \mu \mathrm{m}$ broad as opposed to $5.3-6.7 \mu \mathrm{m})$. The main difference lies in the central pores of $N$. leptostriata which are very closely placed and distinct. Navicula notha J. H. Wallace (Wallace 1960) also overlaps with $N$. nielsfogedii in terms of length $(19-32 \mu \mathrm{m})$ but is generally narrower (breadth 4-5.5 $\mu \mathrm{m}) . N$. notha may be also slightly coarser in striation and areolation (15-17 in $10 \mu \mathrm{m}$ and c. 38 in 10 $\mu \mathrm{m}$ respectively). In addition, the smaller central area as well as the shape of the valve separates it from $N$. nielsfogedii. Navicula heimansioides LANGE-BERTALOT (LANGE-Bertalot 1993) differs by having less striae (14-16 in $10 \mu \mathrm{m})$, a lower number of areolae (32-35 in $10 \mu \mathrm{m})$ and different shaped valve endings. $N$. heimansioides was identified in Sierra Leone by CARTER (1982) as N. feuerbornii. Navicula feuerbornii sensu SiMONSEN (1987) has abruptly rounded ends, is 33-46 $\mu \mathrm{m}$ long and 6-7 $\mu \mathrm{m}$ broad. The striae in the centre are slightly radial (never bent as in $N$. nielsfogedii) to weakly convergent near the apices, 10 in $10 \mu \mathrm{m}$ in the centre to 14 in $10 \mu \mathrm{m}$ towards the ends. Areolae are clearly visible, and it inhabits alkaline waters. None of the above taxa possess a silica structure ('appears superficially as a tongue') in the central pores as does Navicula nielsfogedii.

\section{Taxonomic remarks on Navicula feuerbornii $f$. africana}

Based on studies of the type material of Navicula feuerbornii f. africana (Figs 23-33, taken from the type slide Ghana No 119/1961) we would suggest that this species may be conspecific with Navicula heimansioides. The name Navicula feuerbornii f. africana indicates a link to $N$. feuerbornii. As discussed below this form has little relation to the species $N$. fuerbornii sensu Hustedt. We postulate that Navicula feuerbornii f. africana and Navicula heimansioides may be conspecific based on our examination of the type material of $N$. feuerbornii f. africana. We measured 27 cells on the type slide of $N$. feuerbornii f. africana from Ghana and found that the populations of $N$. heimansioides discussed by LANGE-BERTALOT (2002) overlap in respect to length, breadth and number of striae (see Table 1) as well as in the shape of the valve apex. The cells we measured on the type slide differed in one respect from FOGED's initial description; he stated that the cells had 15 striae in $10 \mu \mathrm{m}$ but his drawing shows a valve with 17 striae in $10 \mu \mathrm{m}$. Our measurements of cells from the type population also show an average of 17 striae in $10 \mu \mathrm{m}$.

\section{Species concept drift}

When diatoms were first systematically studied and documented, a brief description was accompanied by an often minute drawing (e.g. KüTZING 1844). These drawings were also made from freshly collected material or material dried to thin sheets of mica. Surprisingly, despite this some species concepts remain remarkably stable (see discussion in TAYLOR \& CoCQUYT 2015). However, other concepts can prove to be far less stable, especially when the original author of

Table 1. Morphometric data on the studied population from LANGE-BERTALOT (2002), Ghana (119/1961) and DR Congo (CCA 2071).

\begin{tabular}{|c|c|c|c|c|c|}
\hline Taxon & $\begin{array}{l}\text { Number of } \\
\text { cells } \\
\text { measured }\end{array}$ & $\begin{array}{l}\text { Valve length }(\mathrm{L}) \\
(\mu \mathrm{m})\end{array}$ & $\begin{array}{l}\text { Valve } \\
\text { breadth }(\mathrm{B}) \\
(\mu \mathrm{m})\end{array}$ & L:B ratio & $\begin{array}{l}\text { Striae } \\
\text { in } 10 \mu \mathrm{m}\end{array}$ \\
\hline $\begin{array}{l}\text { Navicula heimansioides } \\
\text { (LANGE-BERTALOT 2002) }\end{array}$ & unknown & $30-50$ & $5-6$ & 6.9 & $14-16$ \\
\hline $\begin{array}{l}\text { Navicula feuerbornii f. africana } \\
\text { (FogED type Ghana No. 119/1961) }\end{array}$ & 27 & $40-50$ & $5.3-6.3$ & 7.4 & $16-17$ \\
\hline $\begin{array}{l}\text { Navicula nielsfogedii sp. nov. } \\
\text { (DRC population CCA 2071) }\end{array}$ & 70 & $23-43$ & $5.5-6.7$ & 5.4 & $17-18$ \\
\hline
\end{tabular}




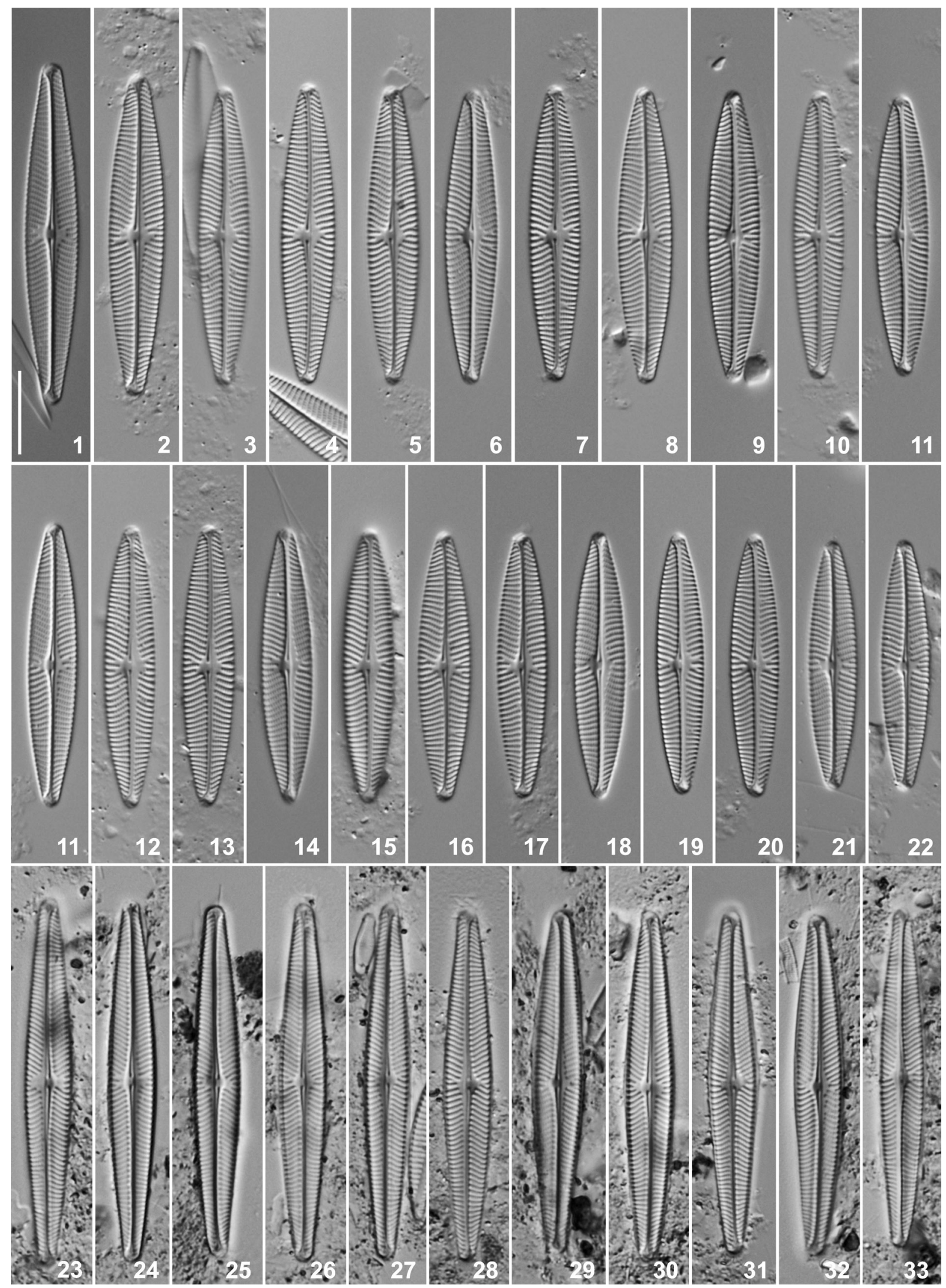

Figs 1-22. LM of type material of Navicula nielsfogedii from sample CCA2071.

Figs 23-33. LM of type material of Navicula feuerbornii f. africana from sample Ghana 119/1961. Scale bar $10 \mu \mathrm{m}$. 

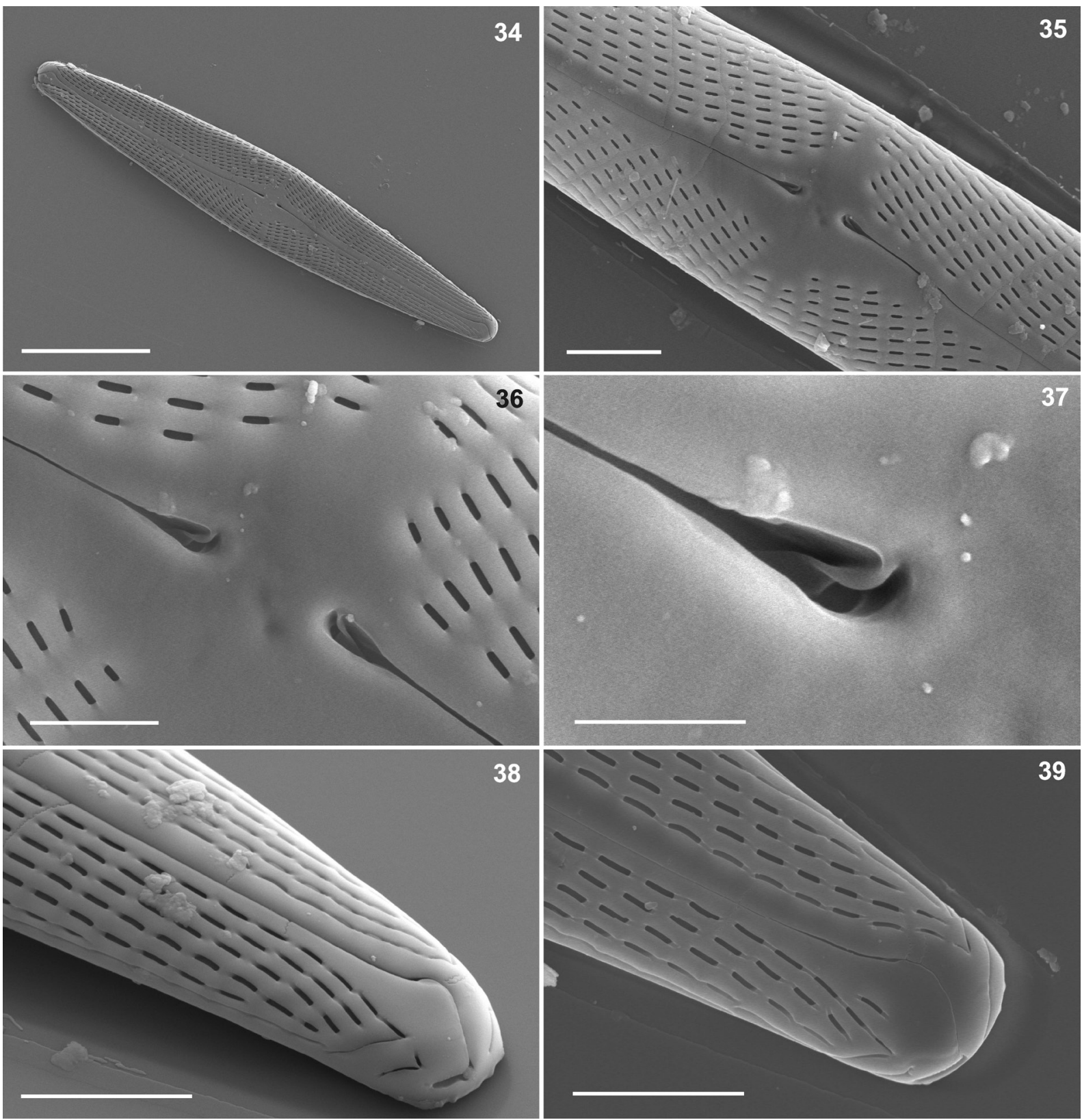

Figs 34-39. SEM of type material of Navicula nielsfogedii from sample CCA2071: (34) external view of complete valve; (35-37) valve exterior showing detail of the central area and proximal raphe endings, note the structure previously known as a silica tongue in Fig. (37); (38-39) valve apices showing distal raphe endings. Scale bar $10 \mu \mathrm{m}(34), 2 \mu \mathrm{m}(35,38,39), 1 \mu \mathrm{m}(36), 0.5 \mu \mathrm{m}(37)$.

the taxon did not provide a clear species concept. As diatom studies advanced, these organisms were documented, again mostly with drawings, but from cleaned material mounted in media with a high refractive index allowing the morphology of the cell walls to be better observed, and such drawings are often open to interpretation. When photo-microscopy became more accessible and commonly used species concepts could be more firmly established. Added to this, the rules for botanical nomenclature changed in 1958 (MCNEILL et al. 2012) necessitating the description of a species from a single specimen (in the case of diatoms this is a type slide) allowing less room for error in interpretation of the original author's concept by later workers.
Drawings of cells are open to interpretation and shifts come about as one author identifies what he assumes to be a previously described taxon and then he in turn illustrates this taxon himself (his own concept). This new illustration may be more readily available to the scientific community than the original, which often dated from the mid-1800s, and so if the concepts of the species are different the newer illustration may take precedence simply because of the availability of the newer literature. This has been in particular true for Africa, as literature, even now with the availability of electronic resources, is difficult to obtain locally. With drawings as illustrations, and even photographs, these subtle shifts can occur several times distancing 


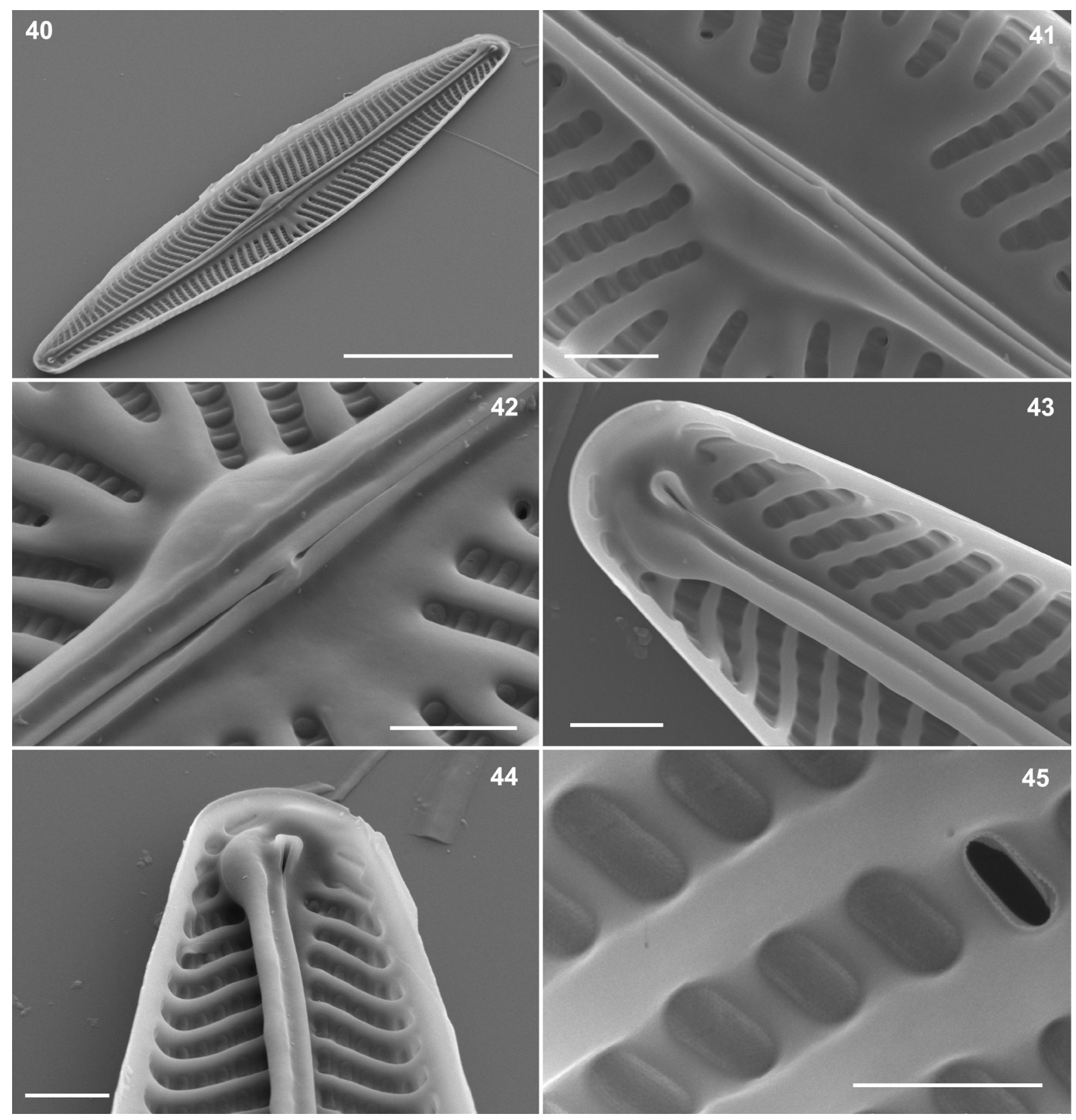

Figs 40-45. SEM of type material of Navicula nielsfogedii from sample CCA2071: (40) internal view of complete valve; (41-42) valve interior showing detail of the central area and proximal raphe endings, note the unilateral thickening of the central nodule; (43-44) valve apices showing internal distal raphe endings and helictoglossae; (45) detail of the internal occlusion of the areolae by perforated hymenes. Scale bar $10 \mu \mathrm{m}$ (40), $1 \mu \mathrm{m}(42-44), 0.5 \mu \mathrm{m}(45)$.

the species far from its original concept and perhaps even from the generic classification (see also in MoRALES et al. 2013). As mentioned before, with the publication of photographic floras, species concepts became more stable but these stable concepts may still have been based on earlier misinterpretation. There have been several attempts to remedy this problem. SсновMAN AND ARCHIBALD (1976-1980) set about describing in detail the diatom flora (both ubiquitous and endemic) of South Africa by checking the type slide of each species they discussed, collecting together the original drawings, light microscope and electron microscope images. Unfortunately for a number of reasons this work was discontinued. Recently however, there has been a resurgence within the diatom community of the notion that we cannot accurately describe and discuss the ecology of taxa without referring to the type material (e.g. TAYLOR \& COCQUYt 2015; Wetzel et al. 2013; Morales et al. 2013). A very good example of such taxonomic confusion may be found in Navicula feuerbornii. This species was originally described from Java by HusTEDT (1938) from two discrete populations comprising drawings of valves of each population without stipulating which was the type. From the drawings and from the later photographs of the type (SIMONSEN 1987) it can be clearly seen that the two populations were 


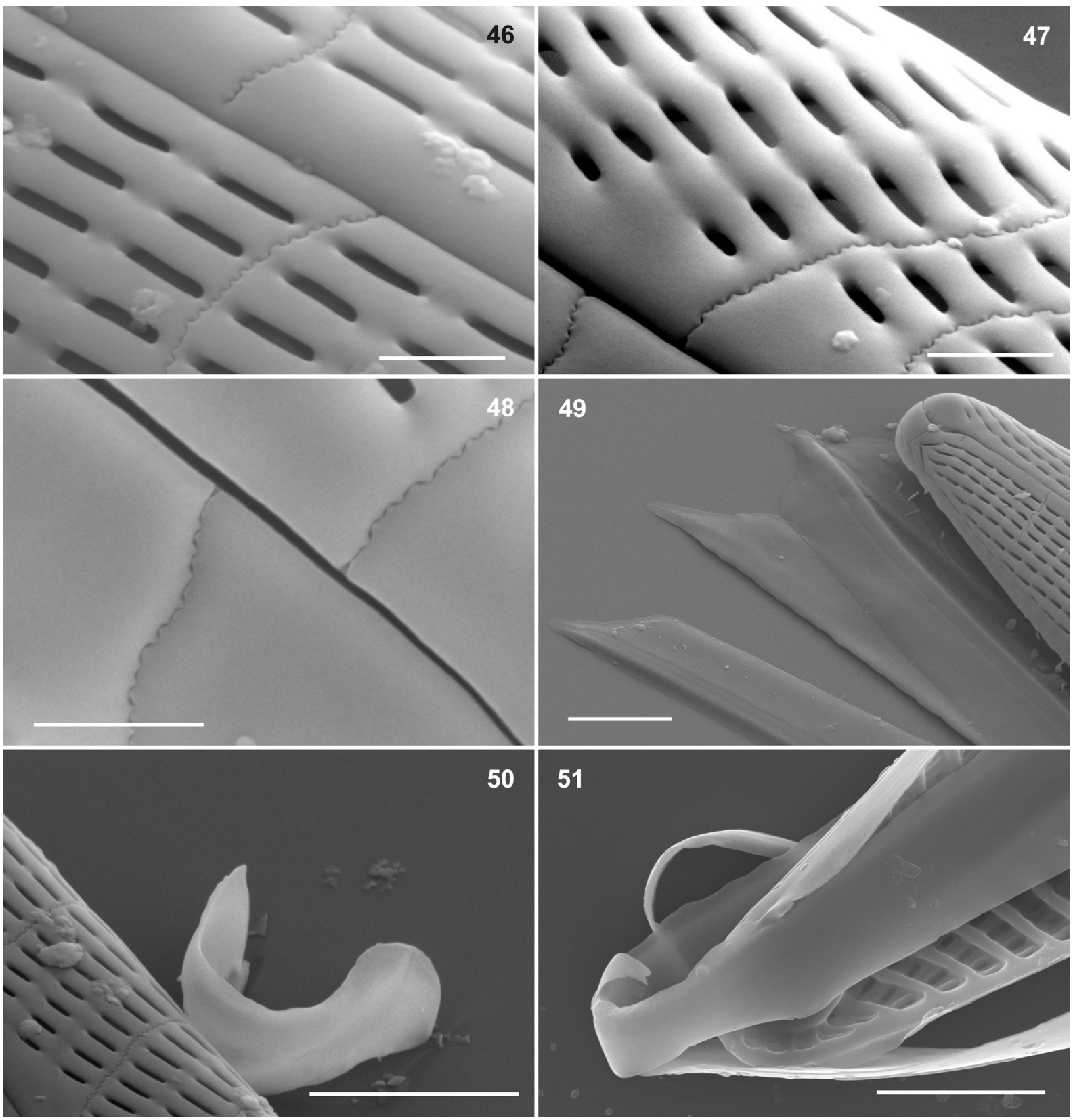

Figs 46-51. SEM of type material of Navicula nielsfogedii from sample CCA2071: (46-48) external view of valve showing suture like structures; (49-51) structure of the copulae, long bands shown in Fig. (49) and (51), and complimentary short band in Fig. (50). Scale bar $0.5 \mu \mathrm{m}$ (46-48), 2 um (49-51).

comprised of distinct taxa with several distinct valve features (these will not be further discussed as it is not the purpose of the present paper to resolve this issue). In this case the author himself had a broad concept of his own species, making it more difficult for other later workers to define theirs (cf. Nitzschia epiphyticoides Hustedt, Cocouyt et al. 2012). Foged in his work on the diatoms of Ghana (FogED 1966) illustrates N. feuerbornii and also describes a new forma of this taxon N. feuerbornii f. africana. (Foged accidentaly listed his taxon as $N$. feuerbornii var. africana on page 156 in his 'Index to species'.) However, if we compare the type of $N$. feuerbornii HustedT, even though the con- cept is broad, there is still only a small similarity to $N$. feuerbornii as illustrated by FOGED. This would not be too problematic but FogED then goes on to describe a forma of this taxon, of which he has his own concept, so the resulting situation is the description of a forma which in reality has nothing to do with the true nominate species sensu HustedT and thus taxonomic confusion reigns. This is especially problematic when the taxon in question is common and widespread through the study region.

\section{ACKnowledgements}

We thank Dr N. Lundholm for the Museum Botanicum Hauniense, 
Copenhagen, Denmark for Foged's type material. The research was funded within the projects COABFISH and COZADIMO, both funded by the Belgian Science Policy. J. C. TAYLOR is the recipient of South African National Research Foundation (NRF) incentive funding. Any opinions, findings and conclusions or recommendations expressed in this material are those of the author(s) and therefore the NRF does not accept any liability in regard thereto. J. C. TAYLOR is a beneficiary of a mobility grant from the Marie Curie Actions of the European commission co-financed by the Belgian Federal Science Policy. We wish to thank the anonymous reviewers who greatly contributed to the accuracy of this manuscript.

\section{REFERENCES}

Anonymous (1975): Proposals for a standardization of diatom terminology and diagnoses. - Nova Hedwigia Beihefte 53: 323-354.

Cocquyt, C.; De HAAn, M.; JAHN, R. \& Hinz, F. (2012): Nitzschia epiphytica, N. epiphyticoides, and $N$. pseudepiphytica (Bacillariophyta), three small diatoms from Central and East Africa. - Phycologia 51: 126-134.

Foged, N. (1966): Freshwater diatoms from Ghana. - Det Kongelige Danske Videnskabernes Selskab, Biologiske Shrifter 15: 1-169.

Hustedt, F. (1938): Systematische und ökologische Untersuchungen über die Diatomeen-Flora von Java, Bali und Sumatra anch dem Material der Deutschen Limnologischen Sunda-Expedition. - Archiv für Hydrobiologie, Supplement 16: 1-155, pls 85-98.

JørGENSEn, E.G. (1948). Diatom communities in some Danish lakes and ponds. - Det Kongelige Danske Videnskabernes Selskab, Biologiske Shrifter 5: 1-140.

KüTZING, F.T. (1844): Die Kieselschaligen Bacillarien oder Diatomeen. pp. i-vii, 1-152, pls. 1-30, Nordhausen: zu finden bei W. Köhne.

LAnge-Bertalot, H. (ed.) (2001): Navicula sensu stricto 10 genera separated from Navicula sensu lato Frustulia. - In: Diatoms of Europe, Vol. 2. - 526 pp., Gantner Verlag, Ruggell.

Lange-Bertalot, H. (1993): 85 Neue Taxa und über 100 weitere neu definierte Taxa ergänzend zur Süsswasserflora von Mitteleuropa. - Bibliotheca Diatomologica 27: 1-164.

McNeill, J.; Barrie, F.R.; Buck, W.R.; Demoulin, V.; GreuTER, W.; HaWksworth, D.L.; HerendeEn, P.S.; KNAPP, S.; Marhold, K.; Prado, J.; Prud'homme van Reine, W.F.; Smith, G.F.; Wiersema, J.H. \& Turland, N. (eds.) (2012): International Code of Nomenclature for algae, fungi, and plants (Melbourne Code), adopted by the Eighteenth International Botanical Congress Melbourne, Australia, July 2011 - 208 pp., Koeltz Scientific Books, Königstein.

Morales, E.A.; Guerrero, J.M.; Wetzel, C.E.; Sala, S. \& ECTOR, L. (2013): Unravelling the identity of Fragilaria pinnata Ehrenberg and Staurosira pinnata Ehrenberg: Research in progress on a convoluted story. - Cryptogamie, Algologie 34: 89-102.

Ross, R.; Cox, E.J.; Karayeva, N.I.; Mann, D.G.; Paddock, T.B.B.; SimONSEN, R. \& Sims, P.A. (1979): An amended terminology for the siliceous components of the diatom cell. - Nova Hedwigia Beihefte 64: 513-533.

Schмidt, A.F.W. (1936): Atlas der Diatomaceenkunde.- IX/ pls 385-420, O.R. Reisland, Leipzig.
Schoeman, F.R. \& Archibald, R.E.M. (1976-1980): The diatom flora of Southern Africa. CISR special report-Wat 50. - National Institute for Water Research, Council for Scientific and Industrial Research, Pretoria.

Simonsen, R. (1987): Atlas and Catalogue of the Diatom Types of Friedrich Hustedt, Vols I, II, III. - pp. 525, pls 1-772, J. Cramer, Berlin \& Stuttgart.

TAYlor, J.C. \& CocQuYT, C. (2015): Diatom research in southern and central Africa: Historical perspectives and current activities. Bulletin des Séances, new series 60: accepted.

Wallace, J. (1960): New and variable diatoms. - Notulae Naturae 331: 1-8.

Wetzel, C.E.; Morales, E.A.; Hinz, F.; Bicudo, D.C. \& EcTOR, L. (2013): Fragilariforma javanica comb. nov.: Analysis of type material of a widely reported species with a tropical distribution. - Diatom Research 28: $373-379$

(C) Czech Phycological Society (2016)

Received September 16, 2015

Accepted May 3, 2016 